\title{
Egalitarian distribution of health maintenance using technologies for life extension
}

\author{
Martin Lipovšek \\ University of Ljubljana, Faculty of Arts, Aškerčeva cesta 2, 1000 Ljubljana, Slovenia \\ martin.lipovsek@gmail.com
}

\begin{abstract}
Background and purpose: Background of our paper is the thesis that, under certain conditions, life-extension medical technologies should be available to all citizens through free public health care. The purpose of the proposed thesis is multifaceted. First, by offering life extension, which we define as medical and pharmacological therapies that work against the biological aging process and some of which can be expected in the near future, we would maintain and strengthen the health of the population - including the working population. As a result of these interventions in the body, this population would be more vital in old age and could thus remain active for a longer period of time. Secondly, prolonging life is something that the majority of the population wants - to be healthy and live longer. This thesis can be firmly supported by empirical sociological research. And third, if prolonging life under certain conditions, the main condition of which is recalculated financial eligibility, would be part of public health (and not just what only the rich can buy), it would satisfy our idea of social justice as we can perceive it through egalitarian political-philosophical theories. Presentation of the content: For the above thesis it is possible to present arguments for and against. If we rely on the tradition of the liberal philosophical position represented by John Rawls, we can defend the position presented above. The main argument here is the application of the veil of ignorance to the concrete question of the fair distribution of medical devices. But there are also arguments from some other ethical and political-philosophical traditions. The concept of justice in prolonging life has been extensively written about by dr. Adrian Bunn, to whom we also refer in the article. Conclusions: With the expected arrival of life extension, new questions open up and new ethical and political-philosophical dilemmas emerge. One of these new questions is whether or not to provide some of these new technologies to all citizens to choose freely. The liberal political-
\end{abstract}


philosophical tradition not only allows such new technologies, but under certain conditions places an ethical requirement on society that these technologies are accessible to all, not just to the rich.

Keywords: Key words: public health, life extension, philosophy

\section{Introduction}

The starting point of our paper is the thesis that, under certain conditions, life extension medical technologies should be available to all citizens through free public health care. Medical technologies to prolong life, or in other words longevity technologies, are understood as medical and pharmacological therapies that work against the biological process of ageing (slowing down, stopping, regenerating the body) and some of them can be expected in the near future. As a result of these interventions in the body, the population could be vital longer into old age and thus remain active for a longer period of time. Lipovšek (Lipovšek, 2019) has already written about them in Slovenia, and on a global scale they are presented through the works of de Gray (de Gray, 2008), Sinclair (Sinclair, 2019) and Otin (Lopez-Otin et al, 2013).

Our thesis at the beginning of this paper appeals to the state to set requirements for the operation of free public health. The authors advocate approach of egalitarianism represented by the philosophy of John Rawls (Rawls, 2011) and an additional theoretical assumption. In short, John Rawls places his philosophy of justice on the following foundation. The theory is based on lexical priority. The first principle is "Everyone should have the same right to the most comprehensive system of equal fundamental freedoms, compatible with a similar system of freedoms for all” (Rawls 1971, pp. 302-3) (Kymlicka 2015, p. 94). The second principle reads: "Social and economic inequalities must be regulated in such a way that they are at the same time: a) for the greatest benefit of those at their worst, and b) linked to public services and positions accessible to all under conditions of fair equality of opportunities. First priority rule (priority of freedom) - the principles of justice must be classified lexically and therefore freedom can only be restricted in the name of freedom. Second priority rule (priority of justice over efficiency and well-being) - The second principle of justice is in lexical order over efficiency and before the principle of maximizing the sum of benefits; and the fairness of opportunities precedes the principle of difference"(Rawls 1971, pp. 302-3) (Kymlicka 2015, p. 95). An additional theoretical assumption that the state would distribute life extension services rather than money cannot, unfortunately, be fully substantiated in this paper due to limitations. In practice, it can be quickly defended - because the state may have a greater interest in distributing services than individuals to buy life extensions. A philosophical rationale, however, would require extensive argumentation and consideration of whether it can be derived from Rawls 'philosophy. To make the initial thesis from the beginning of the article clear, we will present what we mean by the phrase "certain conditions". Certain conditions 
may be such that the state is bound by ethics and justice to provide life extension unconditionally or is conditionally bound to do so. In our paper, we will only talk about the first option, because the second option would require a discussion that would significantly exceed the limitations of this writing. Let us first look at the specific conditions in which we claim that the state is obliged to extend life unconditionally. We will also use an example to illustrate the conditions. Some of the conditions for life extension must be: life extension technologies are easy to distribute, the cost is relatively low, efficiency is scientifically validated and quantified, the gain of extra healthy years of life is relatively large, side effects are relatively negligible and people can freely choose whether or not to participate in life extension technologies. The key condition, however, is that after a certain number of years, when the program of free distribution of life extension technologies begins, the state treasury has gained or at least lost nothing financially with the costs of the program. By this, we mean that if we add up the costs of these technologies and all the costs involved (bureaucracy, distribution, control, awareness, the cost of waiting for the return of state investment in the program), these are less than or equal to the inflow into the state treasury because of the following things. Successful and effective life extension technologies are pushing the ratio of healthy years of life to sick years of life significantly in favour of healthy years. As a result, the costs the public health system has with these people are much lower. People with longer and healthier lives can work longer and thus pay taxes for longer. For example, by looking after grandchildren and great-grandchildren, by being consultants in companies and institutions, by workong in socially beneficial organizations they also benefit the society. A realistic example in which the state would be unconditionally obliged to provide life extension is if we had evidence that metformin is extremely effective. A multi-year study of TAME in the USA is currently being prepared, which will scientifically study the effect of metformin on life expectancy and health on a very large sample of people (Tame trial, 2020). Metformin is exceptionally cheap due to the expired patent, 100 tablets in Slovenia cost $5 €$ (Javna agencija RS, 2019). Realistically, we can imagine that metformin will turn out to be a drug that statistically adds a few healthy years of life to the average person. And from accurate data, we could calculate whether the state investment in the metformin program would be fully refunded or not. The state would be conditionally obliged to prolong life if the total cost of the life extension program was greater than the financial income from it. We use the word conditionally because in this case it would be necessary to take money away from other areas of the budget (health or overall), which would mean setting priorities. For example, if metformin were very expensive and the funds could only be drawn from the health fund, there could be a dilemma as to whether the funds could be used for people who want to prolong their lives or treat cancer.

We can argue for a practical defense of a situation in which certain conditions are met, so that the provision of life extension can be described as uncon- 
ditionally necessary. The health and sustainability of the working population would be strengthened. Social investment in people (schooling and training) would be maintained for a longer period of time. If people would like to do this themselves, we can also assume that they would be happier because of it. Otherwise, they could stop using life extension technologies on a regular basis (the authors of the article also defend the opinion that based on the argument from autonomy, people should also have the right to euthanasia if they suffer immensely). The general argument against prolonging life is the problem of limited global resources. However, since we are not talking about a miracle potion for immortality but for a few more years of health that would help the economy or leave intact, then we see that this accusation is not solid. According to our scenario, we have intact investment opportunities in green technologies. The practical defence also includes the opinion of the people - they clearly want life extension technologies, which means that there is a democratic will and preference for these technologies. The opinion of Slovenes was found in a sociological survey from the spring of 2020 on 761 respondents. The results of the research were presented at two conferences - the international conference Metchnikoff Day Conference and the Slovenian conference Being a hundred years young. To the question "If I had the opportunity, I would use biomedical therapies if they enable us a longer and healthier life." $24 \%$ of people answered with strongly agree, $57 \%$ agree, $15 \%$ disagree and $4 \%$ strongly disagree. People want more activities of the state: "I want the state to invest in the development of biomedical therapies that would enable longer and healthier life." On this question, 26\% of people answered with I completely agree, $56 \%$ agree, $12 \%$ disagree and $6 \%$ completely disagree. In the end, it is evident that the desire for universal access to life extension is almost unanimous: "I would be angry if biomedical therapies that enable a longer and healthier life were available only to the rich." $64 \%$ answered with I strongly agree, $31 \%$ agree and only $3 \%$ disagree and $2 \%$ strongly disagree (Metchnikoff day, 2020) (Biti mlad sto let, 2020).

Several political-philosophical theories could be used to philosophically address our question. For example, libertarianism, utilitarianism, lexical egalitarianism, and Rawlsian egalitarianism were addressed by Adrian Bunn (Bunn, 2015). We limit ourselves to the last of these. This does not mean that other theories are not relevant or important for some future research. In the case where the state is committed to the conditional provision of life extension technologies, the second principle of Rawls' philosophy, point a), comes into play. We can ask what it is like in the case where the state is committed to the unconditional provision of life extension technologies. In this case, we argue, however, Rawls 'logic follows the first principle of his philosophy of justice presented. Namely, the right to life is a fundamental freedom and also the right to health. And if the exercise of these two rights does not conflict with the rights of other people, as in our case (for example, a cancer patient is not harmed in any way), then people can unconditionally claim the above rights for themselves. Their demand stems from the principle of freedom, not just from the 
principle of equal distribution of economic goods. If a state follows Rawls' logic of justice and the additional theoretical assumption that it must provide services not just money, then it is obligated to do what the initial thesis of the paper speaks of.

\section{Conclusion}

To conclude, Aubrey de Gray, at the conference Being Hundred Years Young (Biti mlad sto let, 2020), when he was asked about the fairness of life extension technologies, he simply answered that this is not a problem at all. When efficient technologies will come, they will pay for themselves and states will therefore provide them to all the citizens.

\section{References}

BUNN, A., 2015. How Long Ought We To Live: The Ethics of Life Extension. Australia: Charles Sturt University [online]. [viewed 2 February 2020] Available from: https://researchoutput.csu.edu.au/en/publications/how-longought-we-to-live-the-ethics-of-life-extension-3

BITI MLAD STO LET, 2020. Online conference. 11., 12. June 2020 [online]. Available from: https://www.youtube.com/channel/UCntIac4uqExLp4qMxvz25eQ/videos

DE GREY, A. D. N. J., 2008. Ending aging: the rejuvenation breakthroughs that could reverse human aging in our lifetime. New York: St. Martin's Griffin. $433 \mathrm{p}$.

JAVNA AGENCIJA RS ZA ZDRAVILA IN MEDICINSKE PRIPOMOČKE, 2019. Seznam veljavnih cen zdravil. 60-3/2019 [online]. [viewed 10. July 2019]. Available from: https:/www.jazmp.si/fileadmin/datoteke/seznami/SFE/Cene/cene_20190215.pdf

KYMLICKA, W., 2015. Sodobna politična filozofija: uvod, Ljubljana: Krtina. Editor: Igor Pribac. 685 p.

LIPOVŠEK, M., 2019. Etična in družbena vprašanja ob podaljševanju življenja v bližnji prihodnosti. in: IGNJATOVIĆ, M., KANJUO-MRČELA, A, KUHAR, R. eds. Znanost in družbeprihodnosti. Slovensko sociološko srečanje, Bled, 18.-19. oktober 2019. Ljubljana: Slovensko sociološko društvo. pp. 4953.

LÓPEZ-OTÍN, C., BLASCO, M. A., PARTRIDGE, L., SERRANO, M., KROEMER, G., 2013. The hallmarks of aging. Cell, 153(6), pp. 1194-1217.

RAWLS, J., 2011. Pravičnost kot poštenost : reformulacija. Ljubljana: Krtina. Other authors: ZAKRAJŠEK, K,, PRIBAC, I. 274 str.

SINCLAIR, D. A. AND M. D. LAPLANTE, 2019. Lifespan: Why We Age-and Why We Don't Have To, Atria Books. 432 p.

TAME TRIAL, 2020 [online]. [viewed 13. July 2020]. Available from: https:// www.afar.org/tame-trial 
THE 1ST METCHNIKOFF'S DAY ONLINE CONFERENCE - AGING, IMMUNITY AND COVID-19, 2020. May 16, 2020 [online]. Available from: http://www.longevityalliance.org/?q=1st-metchnikoff-s-day-online-conference-aging-immunity-and-covid-19-may-16-2020\& fbclid=IwAR2ytke5OQzVLTq4BKW8w2lxgPgib6N61UTjm1qFVqxTYgXKjc4UqCgr14 